\title{
Synthesis and anti-HIV evaluation of novel 1,3-disubstituted thieno[3,2-c][1,2,6]thiadiazin-4(3H)-one 2,2-dioxides(TTDDs)
}

\author{
Yongqiang Lin, ${ }^{\mathrm{a}}$ Xinyong Liu, ${ }^{\mathrm{a}, *}$ Renzhang Yan, ${ }^{\mathrm{a}} \mathrm{Jin} \mathrm{Li},{ }^{\mathrm{a}}$ Christophe Pannecouque, \\ Myriam Witvrouw ${ }^{\mathrm{b}}$ and Erik De Clercq ${ }^{\mathrm{b}, *}$ \\ anstitute of Medicinal Chemistry, School of Pharmaceutical Sciences, Shandong University, \\ No. 44 Wenhuaxi Road, Jinan 250012, China \\ ${ }^{\mathrm{b}}$ Rega Institute for Medical Research, Katholieke Universiteit Leuven, B-3000 Leuven, Belgium
}

Received 6 August 2007; revised 24 September 2007; accepted 2 October 2007

Available online 10 October 2007

\begin{abstract}
A series of novel 1,3-disubstituted thieno[3,2-c] [1,2,6]thiadiazin-4(3H)-one 2,2-dioxides (TTDDs), designed as non-nucleoside reverse transcriptase inhibitors (NNRTIs), was synthesized, structurally confirmed by spectral analysis and evaluated for their anti-HIV-1 activities by inhibition of HIV-1(IIIB)-induced cytopathogenicity in MT-4 cell culture. The results showed that TTDD analogues exhibited marked potency as anti-HIV-1 agents. The most active and selective compound was 1-(3-cyano)benzyl-3-benzyl-thieno[3,2-c][1,2,6]thiadiazin-4(3H)-one 2,2-dioxide (5f) with a $50 \%$ effective concentration $\left(\mathrm{EC}_{50}\right)$ of $4.0 \mu \mathrm{M}$ and a selectivity index (SI) of $>76$. The structure-activity relationship (SAR) is discussed.
\end{abstract}

(C) 2007 Elsevier Ltd. All rights reserved.

\section{Introduction}

The introduction of highly active anti-retroviral therapy (HAART) has dramatically decreased the morbidity and mortality from the infection by HIV, the causative agent of acquired immunodeficiency syndrome (AIDS). However, the AIDS prevalence remains one of the world's most serious health problems, causing millions of deaths each year. ${ }^{1}$ The principal chemotherapeutic agents that have been used in the clinic to block the replication of HIV are the reverse transcriptase inhibitors (RTIs), protease inhibitors (PIs) and a fusion inhibitor. The HIV-1 reverse transcriptase (HIV-1 RT)-catalyzed step in the life cycle of HIV is an attractive target for anti-AIDS drug development. Three classes of HIV-1 RTIs are currently available: nucleoside (and nucleotide) reverse transcriptase inhibitors (NRTIs, NtRTIs) and non-nucleoside reverse transcriptase inhibitors (NNRTIs). NNRTIs are structurally diverse compounds specifically targeting at an allosteric site of HIV-1 RT, approximately 10-15

\footnotetext{
Keywords: HIV-1 NNRTIs; Thieno[3,2-c][1,2,6]thiadiazine; Synthesis. * Corresponding authors. Tel.: +86 531838 2005; fax: +86 531838 2264 (X.L.); tel.: +32 16337341 ; fax: +32 16337340 (E.D.C.); e-mail addresses: xinyongl@sdu.edu.cn; erik.declercq@rega.kuleuven.ac.be
}

from the polymerase active site, causing a distortion of the catalytic aspartate triad. ${ }^{2,3}$ The efficacy of NNRTIs, and of the other anti-AIDS agents, has been limited by the emergence of drug-resistant viral strains and possible side effects. ${ }^{4-6}$ Therefore, new NNRTIs with more potent activity and lesser toxicity are still needed.

In recent studies aimed at the discovery of new NNRTIs, Dr. S. Vega and his colleagues reported that a series of 2,4-disubstituted-1,1,3-trioxo-2 $H, 4 H$-thieno[3,4-e] $[1,2,4]$ thiadiazines (TTDs) effectively inhibited, at the reverse transcription step, the replication of a variety of HIV-1 strains, including strains that are resistant to AZT (azidothymidine, zidovudine), but not HIV-2 (ROD). ${ }^{7,8}$ The prototype compounds QM96521, QM96539 and QM96639 (Fig. 1), containing a benzyl or 2-halogenated benzyl moiety at the $\mathrm{N}_{2}$ position and a cyanomethyl chain linked to the $\mathrm{N}_{4}$ position, were found to selectively inhibit HIV-1 (III-B) replication in MT and CEM cell cultures. The cross-resistance pattern of these compounds against other NNRTI-resistant mutant HIV-1 strains and molecular modelling of the HIV1 RT binding site were both found to be similar to that of nevirapine. Furthermore, molecular modification by replacement of the $\mathrm{N}_{4}$ cyanomethyl with a substituted benzyl group led to the discovery of a new precursor 


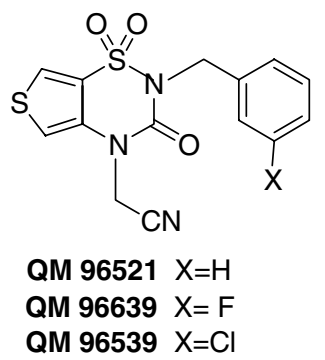<smiles>O=C1N(Cc2ccccc2Cl)c2cscc2S(=O)(=O)N1Cc1ccccc1</smiles>

QM 96625

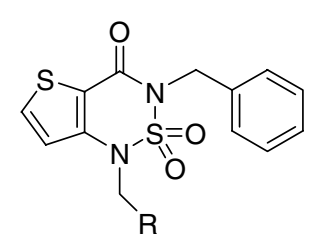

1,3-Disubstituted-thieno[3,2-c][1,2,6]

thiadiazin-4(3H)-one 2,2-dioxides(TTDDs)

Figure 1. Structures of lead compounds TTDs and newly designed TTDDs.

QM96625 $\left(N_{2}\right.$-benzyl, $\quad N_{4}$-2-chlorobenzyl, $\quad \mathrm{EC}_{50}=$ $0.1 \mu \mathrm{M}$, SI $>1190$. Fig. 1$)^{7}$

Initial structure-activity relationship analysis together with the molecular modelling disclosed that double substitutions containing $\pi$-electrons at the $\mathrm{N}_{2}$ and $\mathrm{N}_{4}$ sites of TTDs were necessary for preserving anti-HIV-1 activity. Their structure is in perfect accord with the 'butterfly-like' three-dimensional (3D) model proposed by Schafer et al. ${ }^{10}$

In continuing research of the new HIV-1 NNRTIs and study of the structure-activity relationships of TTD analogues, we designed a series of novel 1,3-disubstituted thieno[3,2-c][1,2,6]thiadiazin-4(3H)-one 2,2-dioxides (TTDDs) based on the general principle of bioisosteric replacement in medicinal chemistry, since TTDDs can be considered as the bioisosteres of TTDs. In the newly designed TTDD analogues, the heterocyclic system of thieno[3,2-c] $[1,2,6]$ thiadiazin-4(3H)-one 2,2-dioxide served as a scaffold. The benzyl group at $\mathrm{N}_{3}$ position, benzyl, substituted benzyl, cyanomethyl and other groups containing $\pi$-electrons at $\mathrm{N}_{1}$ position, which proved essential for anti-HIV activity in TTD analogues, were respectively introduced in the TTDD nuclear ring, so as to arrange molecules in 'butterfly-like' orientation, which is thought to be the determinant for potent anti-HIV-1 activity of the NNRTIs. ${ }^{9}$ Here, we report the synthesis of novel TTDD analogues and their anti-HIV activity.

\section{Results and discussion}

\subsection{Chemistry}

TTDD acyclonucleosides and two TTDD 1,3-dibenzyl substituted analogues had been synthesized previously and reported as potent human cytomegalovirus (HCMV) inhibitors, ${ }^{11-13}$ in which thieno[3,2-c][1,2,6]thiadiazin-4(3H)-one 2,2-dioxide heterocycle was prepared starting from methyl 3-amino-2-thiophene carboxylate 2 with sulfamoyl $\left(\mathrm{ClSO}_{2} \mathrm{NH}_{2}\right)$ followed by two alkylations at $\mathrm{N}_{1}$ and $\mathrm{N}_{3}$ position, respectively. ${ }^{11}$ Two weaknesses were found in this process: the first-step alkylation at $\mathrm{N}_{1}$ position usually produced a mixture of $N_{1^{-}}$and $N_{1}$, $N_{3}$-disubstituted products; the second-step alkylation at $\mathrm{N}_{3}$ position was found not only difficult to achieve probably due to the steric hindrance, but also the side product of $\mathrm{O}_{4}$-substituted compound was formed concomitantly with the TTDDs. ${ }^{13}$
In order to avoid producing a $N_{1}, N_{3^{-}}$and $N_{1}, O_{4}$-disubstituted TTDDs mixture, an unambiguous synthetic pathway was planned for the preparation of the newly designed TTDDs $\mathbf{5 a}-\mathbf{m}$. Thus, we chose 3 -substituted TTDD 4 as the starting material, which was prepared from methyl 3-amino-2-thiophene carboxylate 2 according to the Cohen and Klarberg procedure, ${ }^{14}$ but with an improvement by one-pot reaction. In brief, to an anhydrous toluene solution of the compound 2, N-benzylsulfamoyl chloride $\mathbf{1}$ dissolved in toluene was added dropwise at room temperature. The obtained solution mixture was stirred for $4 \mathrm{~h}$ at $60^{\circ} \mathrm{C}$ and cooled to room temperature, then neutralized with $5 \%$ aq $\mathrm{KOH}$ to adjust $\mathrm{pH}$ at 11, forming the solution mixture of thiophene sulfamide derivative $\mathbf{3}$. The ring-closure reaction was performed by continuing stirring of the two-phase solution at room temperature for $16 \mathrm{~h}$ without separation of compound 3. The key intermediate of 3-benzyl thieno[3,2-c][1,2,6]thiadiazin-4(3H)-one 2,2-dioxide (4) was precipitated after the water layer was separated and treated with conc. $\mathrm{HCl}$ to adjust $\mathrm{pH}$ at 1 , and purified by recrystallization from ethanol in $45 \%$ of total yield.

Alkylation of $\mathbf{4}$ with cyanomethyl, benzyl or substituted benzyl halides, in the presence of equal molar of sodium hydride $(\mathrm{NaH})$ and $\mathrm{N}, \mathrm{N}$-dimethylformamide (DMF) solvent, achieved the target 1,3-disubstituted TTDDs 5a-m (Scheme 1).

The starting material $N$-benzylsulfamoyl chloride 1 was prepared by the modified Kloek and Leschinsky procedure. ${ }^{15}$ To a cooled $\left(0{ }^{\circ} \mathrm{C}\right)$ solution of benzylamine in $\mathrm{CH}_{2} \mathrm{Cl}_{2}$ was added chlorosulfonic acid cautiously with vigorous stirring. The resulting suspension was stirred for $0.5 \mathrm{~h}$ at room temperature and then filtered. The collected solids of $N$-benzylsulfamate were dissolved in toluene and treated with phosphorus pentachloride. The solution was refluxed for $1 \mathrm{~h}$ and the solid was filtered off. The filtrate was concentrated in vacuo, and the syrupy residue ( $N$-benzylsulfamoyl chloride 1) thus obtained was used in the next synthetic step without further purification.

\subsection{Anti-HIV evaluation}

The activity and cytotoxicity of the newly designed and synthesized TTDDs $\mathbf{4}$ and $\mathbf{5}$ were tested in MT-4 cells for inhibition of HIV-1-induced cytopathogenicity. The results are listed in Table 1. The precursors QM96521 and QM96625 were used as reference 


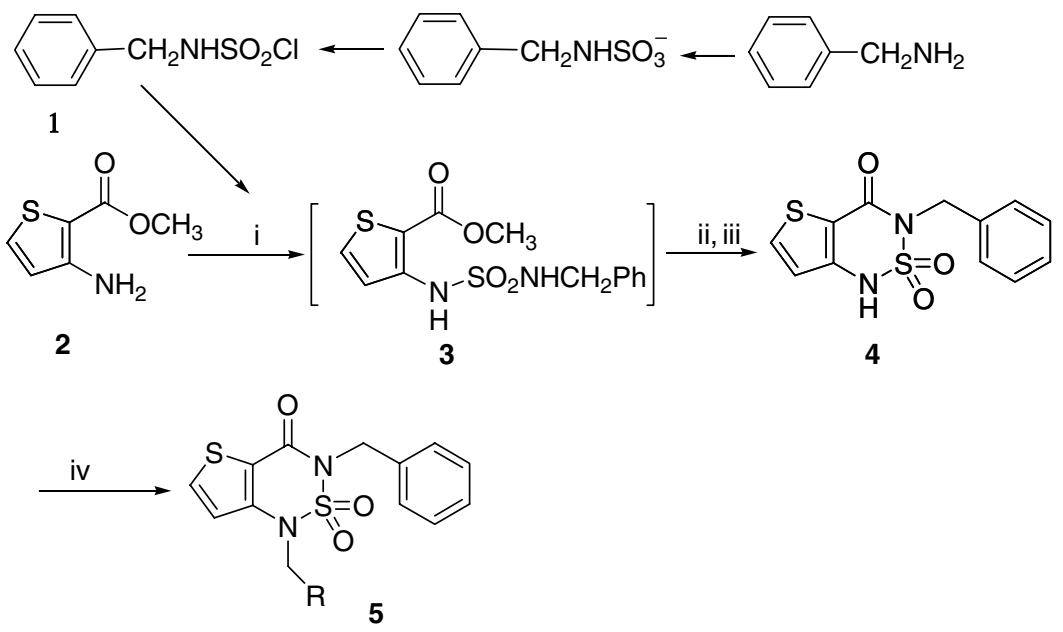

Scheme 1. Reagents: (i) toluene/ $N$-benzylsulfamoyl chloride; (ii) $\mathrm{H}_{2} \mathrm{O} / 5 \% \mathrm{KOH}$; (iii) $\mathrm{H}_{2} \mathrm{O} / \mathrm{HCl}$; (iv) $\mathrm{DMF} / \mathrm{NaH} / \mathrm{RCH}_{2} \mathrm{Cl}$.

Table 1. Structure, anti-HIV-1 activity and cytotoxicity of 1,3-disubstituted thieno[3,2-c][1,2,6] thiadiazin-4(3H)-one 2,2-dioxide (TTDD) analogues 4 and $\mathbf{5 a}-\mathbf{m}$<smiles>[R]CN1c2ccsc2C(=O)N(Cc2ccccc2)S1(=O)=O</smiles>

\begin{tabular}{|c|c|c|c|c|}
\hline \multirow[t]{2}{*}{ Compound } & \multirow[t]{2}{*}{$\mathrm{CH}_{2} \mathrm{R}$} & \multicolumn{3}{|c|}{ HIV-1 ( $\left.\mathrm{III}_{\mathrm{B}}\right)$} \\
\hline & & $\mathrm{EC}_{50}^{\mathrm{a}}(\mu \mathrm{M})$ & $\mathrm{CC}_{50}^{\mathrm{b}}(\mu \mathrm{M})$ & $\mathrm{SI}^{\mathrm{c}}$ \\
\hline 4 & $\mathrm{H}$ & $>373.9$ & 373.9 & $<1$ \\
\hline $5 \mathbf{a}$ & Benzyl & $>37.5$ & 37.5 & $<1$ \\
\hline $5 \mathbf{b}$ & 2-Cl-Benzyl & 4.8 & $>298.6$ & $>62$ \\
\hline $5 c$ & 2-Br-Benzyl & 7.3 & $>270.0$ & $>37$ \\
\hline 5d & 2-CN-Benzyl & 5.1 & $>305.5$ & $>59$ \\
\hline $5 e$ & 3-Cl-Benzyl & 5.9 & $>298.6$ & $>51$ \\
\hline $5 f$ & 3-CN-Benzyl & 4.0 & $>305.5$ & $>76$ \\
\hline $5 g$ & 2,4-Cl -benzyl & 52.1 & 247.1 & 5 \\
\hline $5 \mathrm{~h}$ & 4-Cl-Benzyl & $>8.2$ & 8.2 & $<1$ \\
\hline $5 i$ & 4-Br-Benzyl & $>6.6$ & 6.6 & $<1$ \\
\hline $5 \mathbf{j}$ & 4-CN-Benzyl & $>8.5$ & 8.5 & $<1$ \\
\hline $5 \mathbf{k}$ & 4-NO $\mathrm{NO}_{2}$-Benzyl & $>268.0$ & 268.0 & $<1$ \\
\hline 51 & $\mathrm{CH}_{2} \mathrm{CN}$ & $>5.7$ & 5.7 & $<1$ \\
\hline $5 \mathrm{~m}$ & $\mathrm{CH}_{3}$ & 71.0 & 202.4 & 3 \\
\hline QM96521 ${ }^{\mathrm{d}}$ & $\mathrm{CH}_{2} \mathrm{CN}$ & 0.9 & 502.7 & 559 \\
\hline QM96625 & 2-Cl-Benzyl & 0.1 & $>119.0$ & $>1190$ \\
\hline Nevirapine $^{\mathrm{d}}$ & & 0.03 & 683 & 22,767 \\
\hline $\mathrm{AZT}^{\mathrm{d}}$ & & 0.0007 & 35.6 & 50,587 \\
\hline
\end{tabular}

${ }^{\mathrm{a}} \mathrm{EC}_{50}: 50 \%$ effective concentration, or concentration of compound required to achieve $50 \%$ protection of MT-4 cell from HIV-1 induced cytotoxicity, as determined by the MTT method.

${ }^{\mathrm{b}} \mathrm{CC}_{50}: 50 \%$ cytotoxic concentration, or concentration required to reduce the viability of mock-infected cells by $50 \%$, as determined by the MTT method.

${ }^{\mathrm{c}}$ SI: selectivity index $\left(\mathrm{CC}_{50} / \mathrm{EC}_{50}\right)$.

${ }^{\mathrm{d}}$ Values for anti-HIV-1 activities reported in Refs.7-9. All data represent mean values for at least two separate experiments.

compounds for comparative purposes; AZT (Zidovudine) and nevirapine were used as the reference drugs. The new TTDDs derivatives were confirmed to be both potent and selective HIV-1 inhibitors.

Compounds $\mathbf{5 b}-\mathbf{f}$ emerged as the most active HIV-1 inhibitors with $\mathrm{EC}_{50}$ values in the range of 4-7 $\mu \mathrm{M}$ and the selective indexes (SI, ratio of $\mathrm{CC}_{50}$ for cell growth to $\mathrm{EC}_{50}$ for virus replication) in the range between 37 and 76. The most active and selectivity TTDD derivative was compound 5 f $\left(N_{1}\right.$ - 3-Cl-benzyl, $N_{3}$-benzyl) with an $\mathrm{EC}_{50}$ value of $4.0 \mu \mathrm{M}$ and selective index SI $>76$. Compounds $\mathbf{5 g}$ and $\mathbf{5 m}$ proved slightly active against HIV-1, while compounds $\mathbf{4}$ and $\mathbf{5 k}$ were totally 
inactive. Other compounds displayed no selectivities because of the high cytotoxicity, compounds $\mathbf{5 h}-\mathbf{j}$ and $\mathbf{5 l}$ being cytotoxic for MT-4 cells at concentrations lower than $10 \mu \mathrm{M}$. In addition, all synthesized compounds were screened for activity against HIV-2 (strain ROD), but none of the compounds was found to inhibit HIV2 replication.

These biological data led us to take into consideration the structure-activity relationship (SAR) analysis of these compounds. The active anti-HIV-1 agents were the $N_{1}, N_{3}$ - disubstituted TTDDs, $N_{3}$-monosubstituted derivative $\mathbf{4}$ was inactive, which is accordant with the results obtained for the SAR in the TTD series. Apparently, the molecule that lacked the $N_{1}$-substituent did not meet the structural requirements of the 'butterflylike' conformation, which seems particularly important in other known NNRTIs, i.e. TIBO, $\alpha$-APA, nevirapine and thiazolidones. ${ }^{16}$ The essential substituents are arylmethyl groups such as benzyl, or substituted benzyl. Other groups having no $\pi$-electron character, such as alkyl (5m), lost or decreased the potency and selectivity against HIV-1 replication.

In the $N_{1}, N_{3}$-disubstituted benzyl series $(\mathbf{5 a}-\mathbf{k})$, the activities of the substituents at $N_{1}$-benzyl group were found in the following declining trends: the ortho and meta substituted benzyl $(\mathbf{5 b}-\mathbf{f})>2,4-\mathrm{Cl}_{2}$-benzyl $(\mathbf{5 g})>$ para substituted benzyl $(\mathbf{5 h}-\mathbf{k})$. The results demonstrated that the $N_{1}-O$-substituted benzyl groups were still effective substituents, as previously reported for the SAR of the TTDs, ${ }^{7}$ and further indicated that the introduction of $m$-substituted benzyl group in the $\mathrm{N}_{1}$ position could also result in the congeners endowed with the equivalent potency and selectivity. Whereas the $\mathrm{N}_{1}$ para (p) substituted benzyls, such as 2,4-dichlorobenzyl 5g, $p$ halogenatedbenzyl $\mathbf{5 h}-\mathbf{i}, p$-cyanobenzyl $\mathbf{5 j}$ and $p$-nitrobenzyl 5k, had reduced or abolished activities in contrast to the ortho and meta monosubstituted benzyl anologues, which might reflect a spatial restriction in the target site of the HIV-1 enzyme. This feature can be used in the design of new TTDDs.

The newly designed TTDD compounds presented decreased activities, leading us to hypothesize that the changed positions of the heteroatoms $\mathrm{N}$ and $\mathrm{S}$ in the TTDD heterocycle, giving rise to the changed direction of 'butterfly wing', affected the binding orientation in the aromatic-rich non-nucleoside binding site of HIV-1 RT, surrounded by the aromatic side chains, such as Tyr181, Tyr188, Phe227 and Trp 229. In particular, it affected $\pi-\pi$ interaction of the phenyl ring with the Tyr181 side chain. ${ }^{5,7}$ Molecular modelling of TTDDs by AutoDocking analysis is underway.

\section{Conclusions}

In summary, we designed and synthesized a series of novel 1,3-disubstituted thieno[3,2-c][1,2,6]thiadiazin$4(3 H)$-one 2,2-dioxides (TTDDs), which were structurally confirmed by IR, ${ }^{1} \mathrm{H}$ NMR, ${ }^{13} \mathrm{C}$ NMR and MS spectral analysis and evaluated for their anti-HIV
(HIV-1 III $_{\mathrm{B}}$ and HIV-2 ROD) activities by inhibition of HIV-induced cytopathogenicity in MT-4 cell cultures. The results showed that TTDD analogues exhibited high potency as anti-HIV-1 agents. The most active and selective compound was $\mathbf{5 f}$ with an $\mathrm{EC}_{50}$ value of $4.0 \mu \mathrm{M}$ and a SI of $>76$. TTDD analogues may seem promising for further activity optimization studies.

\section{Experimental}

\subsection{Chemistry}

Melting points were determined on a Gallenkamp capillary apparatus and are uncorrected. ${ }^{1} \mathrm{H}$ NMR $(600 \mathrm{MHz})$ and ${ }^{13} \mathrm{C}$ NMR $(150 \mathrm{MHz})$ spectra were obtained on a Bruker Avance-600 instrument in the indicated solvent. Chemical shifts are expressed in $\delta$ units with tetramethylsilane (TMS) as internal reference. Infrared spectra (IR) were recorded with a Nexus 470FT-IR Spectrometer. Mass spectra were recorded on a LC Autosampler Device: Standard G1313A instrument. All compounds were routinely checked by TLC on pre-coated silica gel $\mathrm{G}$ plates with fluorescent indicator at $254 \mathrm{~nm}$, which were prepared in our laboratory. Developed plates were visualized by UV light. Solvents were of reagent grade and, when necessary, were purified and dried by standard methods. Concentration of the reaction solutions involved the use of rotary evaporator under reduced pressure.

4.1.1. $\mathrm{N}$-Benzylsulfamoyl chloride (1). To a $0{ }^{\circ} \mathrm{C}$ cooled and stirred solution of benzylamine $(10.7 \mathrm{~g}, 0.1 \mathrm{~mol})$ in $\mathrm{CH}_{2} \mathrm{Cl}_{2} \quad(100 \mathrm{~mL})$ was added chlorosulfonic acid $(3.49 \mathrm{~g}, 0.03 \mathrm{~mol})$ cautiously. The resulting suspension was stirred for $0.5 \mathrm{~h}$ at room temperature and then filtered. The collected solids of $N$-benzylsulfamate were dissolved in toluene $(50 \mathrm{~mL})$ and treated with phosphorus pentachloride $(6.24 \mathrm{~g}, 0.03 \mathrm{~mol})$. A mild exothermic reaction took place. The solution was refluxed for $1 \mathrm{~h}$ and the solid was filtered off. The filtrate was concentrated in vacuo and $N$-benzylsulfamoyl chloride 1 was obtained as syrupy residue.

4.1.2. 3-Benzyl- $1 H$-thieno[3,2-c||1,2,6]thiadiazin-4(3H)one 2,2-dioxide (4). To an anhydrous toluene solution of the 3-amino-2-thiophene carboxylate (2) (2.30 g, $0.015 \mathrm{~mol}$ ), $N$-benzylsulfamoyl chloride (1) dissolved in toluene was added dropwise at room temperature. The obtained mixture solution was stirred for $4 \mathrm{~h}$ at $60^{\circ} \mathrm{C}$ and cooled to room temperature, then neutralized with $5 \%$ aq $\mathrm{KOH}$ to adjust $\mathrm{pH}$ at 11 , forming the mixture solution of thiophene sulfamide derivative 3 . The ring-closure reaction was performed without separation of compound 3 by continuing stirring of the two-phase solution at room temperature for $16 \mathrm{~h}$. The intermediate 4 was precipitated after the water layer was separated and treated with conc. $\mathrm{HCl}(\mathrm{pH} \mathrm{1})$, and purified by recrystallization from ethanol in $45 \%$ of total yield. mp $180-182{ }^{\circ} \mathrm{C} .{ }^{1} \mathrm{H}$ NMR (DMSO- $\left.d_{6}\right) \delta: 8.02(\mathrm{~d}, 1 \mathrm{H}$, $J=5.2 \mathrm{~Hz}$, thiophene), 7.35-7.26 (m, 5H, benzene), $7.25(\mathrm{~m}, 1 \mathrm{H}, \mathrm{NH}), 6.93(\mathrm{~d}, 1 \mathrm{H}, J=5.1 \mathrm{~Hz}$, thiophene), $4.97\left(\mathrm{~s}, 2 \mathrm{H}, \mathrm{CH}_{2}\right) ;{ }^{13} \mathrm{C}$ NMR (DMSO- $\left.d_{6}\right) \delta: 158.67$ 
$(\mathrm{C}=\mathrm{O}), \quad 137.22(\mathrm{C}-1), \quad 135.28,128.52(3 \mathrm{C}), \quad 127.97(3 \mathrm{C})$, $127.55,121.41(\mathrm{C}-7), 44.30\left(\mathrm{CH}_{2}-\mathrm{N}_{3}\right)$; IR $\left(\mathrm{KBr}, \mathrm{cm}^{-1}\right)$ : $3274\left(\mathrm{~N}_{1}-\mathrm{H}\right), 3094(\mathrm{Ar}-\mathrm{H}), 1645(\mathrm{C}=\mathrm{O}), 1490$ (Ar, CC), 1373, $1179\left(\mathrm{SO}_{2}\right)$; ESI-MS: $m / z 295.4[\mathrm{M}+1]$.

4.1.3. General procedure for the preparation of 1,3-disubstituted TTDDs (5a-m). To a solution of the 3-benzyl- $1 H$ thieno[3,2-c] $[1,2,6]$ thiadiazin-4(3H)-one 2,2-dioxide (4) $(1.2 \mathrm{~g}, 4 \mathrm{mmol})$ in dry $\operatorname{DMF}(15 \mathrm{~mL})$, under $\mathrm{N}_{2}$, was added sodium hydride $(60 \%$ dispersion in mineral oil, $0.24 \mathrm{~g}, 6 \mathrm{mmol}$ ) by portions, maintaining the temperature below $10{ }^{\circ} \mathrm{C}$. After $15 \mathrm{~min}$, the alkyl halide $(6 \mathrm{mmol})$ was added and the reaction mixture was stirred at $50-80^{\circ} \mathrm{C}$ for $16-24 \mathrm{~h}$. The solvent was evaporated in vacuo to dryness and the crude oil washed with $5 \%$ aq $\mathrm{KOH}$, extracted with $\mathrm{CH}_{2} \mathrm{Cl}_{2}$, evaporated in vacuo and the crude product was recrystallized from the appropriate solvent.

4.1.3.1. 1,3-Dibenzyl-thieno[3,2-c][1,2,6]thiadiazin-4(3H)one 2,2-dioxide (5a). Reagents: Compound 4 (1.2 g, $4 \mathrm{mmol})$, benzyl bromide $(1.0 \mathrm{~g}, 6 \mathrm{mmol})$. Conditions: $60{ }^{\circ} \mathrm{C}, 10 \mathrm{~h}$. Purification: recrystallization. Yield $0.65 \mathrm{~g}$ $(42.3 \%)$ as a white solid: $\mathrm{mp} 96-98^{\circ} \mathrm{C}(\mathrm{EtOH}) ;{ }^{1} \mathrm{H}$ NMR (DMSO- $\left.d_{6}\right) \delta: 8.21(\mathrm{~d}, 1 \mathrm{H}, J=5.4 \mathrm{~Hz}$, thiophene), 7.43-7.13 (m, 11H, benzene and thiophene), $5.16(\mathrm{~s}, 2 \mathrm{H}$, $\left.\mathrm{CH}_{2}\right), 4.97\left(\mathrm{~s}, 2 \mathrm{H}, \mathrm{CH}_{2}\right) ;{ }^{13} \mathrm{C} \mathrm{NMR}\left(\mathrm{DMSO}-d_{6}\right) \delta$ : $157.59(\mathrm{C}=\mathrm{O}), 143.43(\mathrm{C}-1), 136.54(\mathrm{C}-1), 136.12,134.57$, $128.83(2 \mathrm{C}), \quad 128.75(2 \mathrm{C}), \quad 128.55,128.23(4 \mathrm{C}), \quad 128.03$, 121.32, 118.72(C-7), $54.02\left(\mathrm{CH}_{2}-\mathrm{N}_{1}\right), 45.80\left(\mathrm{CH}_{2}-\mathrm{N}_{3}\right)$; IR $\left(\mathrm{KBr}, \mathrm{cm}^{-1}\right): 3104(\mathrm{Ar}-\mathrm{H}), 1666(\mathrm{C}=\mathrm{O}), 1539$ (Ar, C-C), 1371, 1173 (SO $)$; ESI-MS: $m / z$ 385.2 [M + 1].

4.1.3.2. 1-(2-Chloro)benzyl-3-benzyl-thieno[3,2-c][1,2,6]thiadiazin-4(3H)-one 2,2-dioxide (5b). Reagents: Compound 4 (1.2 g, $4 \mathrm{mmol})$, 2-chlorobenzyl chloride (1.0 g, $6 \mathrm{mmol})$. Conditions: $80^{\circ} \mathrm{C}, 18 \mathrm{~h}$. Purification: recrystallization. Yield $0.50 \mathrm{~g}(30 \%)$ as a white solid: mp 83-84 ${ }^{\circ} \mathrm{C}\left(\right.$ EtOH); ${ }^{1} \mathrm{H}$ NMR (DMSO- $\left.d_{6}\right) \delta: 8.16(\mathrm{~d}$, $1 \mathrm{H}, J=5.3 \mathrm{~Hz}$, thiophene), 7.49 (d, $1 \mathrm{H}, J=7.9 \mathrm{~Hz}$ benzene $\mathrm{H}-3), 7.36-7.27(\mathrm{~m}, 8 \mathrm{H}$, benzene), $7.09(\mathrm{~d}, 1 \mathrm{H}, J=$ $5.3 \mathrm{~Hz}$, thiophene), $5.20\left(\mathrm{~s}, 2 \mathrm{H}, \mathrm{CH}_{2}\right), 5.05\left(\mathrm{~s}, 2 \mathrm{H}, \mathrm{CH}_{2}\right)$; ${ }^{13} \mathrm{C}$ NMR (DMSO- $\left.d_{6}\right) \delta$ : $157.64(\mathrm{C}=\mathrm{O}), 143.60(\mathrm{C}-1)$, $136.42(\mathrm{C}-1), 136.11,132.50,132.40,130.23,129.93$, $129.74,128.7$ (2C), 128.15(2C), 127.98, 127.72, 121.04, 118.50(C-7), $51.82\left(\mathrm{CH}_{2}-\mathrm{N}_{1}\right), 45.98\left(\mathrm{CH}_{2}-\mathrm{N}_{3}\right)$; IR $\left(\mathrm{KBr}, \mathrm{cm}^{-1}\right)$ : $3109(\mathrm{Ar}-\mathrm{H}), 1668(\mathrm{C}=\mathrm{O}), 1538$ (Ar, CC), 1373, $1168\left(\mathrm{SO}_{2}\right)$; ESI-MS: $m / z$ 419.2 [M + 1].

4.1.3.3. 1-(2-Bromo)benzyl-3-benzyl-thieno[3,2-c][1,2,6]thiadiazin-4(3H)-one 2,2-dioxide (5c). Reagents: Compound 4 (1.2 g, $4 \mathrm{mmol})$, 2-bromobenzyl bromide (1.5 g, $6 \mathrm{mmol}$ ). Conditions: $60^{\circ} \mathrm{C}, 8 \mathrm{~h}$. Purification: recrystallization. Yield $0.6 \mathrm{~g}(32 \%)$ as a red solid: $\mathrm{mp} 103-105^{\circ} \mathrm{C}$ $(\mathrm{EtOH}) ;{ }^{1} \mathrm{H}$ NMR $\left(\mathrm{DMSO}-d_{6}\right) \delta: 8.16(\mathrm{~d}, 1 \mathrm{H}, J=5.3 \mathrm{~Hz}$, thiophene), $7.67(\mathrm{~d}, 1 \mathrm{H}, J=7.8 \mathrm{~Hz}$ benzene $\mathrm{H}-3), 7.36-$ $7.23(\mathrm{~m}, 8 \mathrm{H}$, benzene), $7.03(\mathrm{~d}, 1 \mathrm{H}, J=5.3 \mathrm{~Hz}$, thiophene), $5.16\left(\mathrm{~s}, 2 \mathrm{H}, \mathrm{CH}_{2}\right) ; 5.06\left(\mathrm{~s}, 2 \mathrm{H}, \mathrm{CH}_{2}\right) ;{ }^{13} \mathrm{CNMR}$ (DMSO-d $\left.d_{6}\right)$ $\delta: 157.72(\mathrm{C}=\mathrm{O}), 143.70(\mathrm{C}-1), 136.49(\mathrm{C}-1), 136.20,134.16$, $133.27,130.45,129.57,128.75(2 \mathrm{C}), 128.43,128.22(2 \mathrm{C})$, $128.04,122.50,120.97,118.53(\mathrm{C}-7), 54.23\left(\mathrm{CH}_{2}-\mathrm{N}_{1}\right)$, $46.09\left(\mathrm{CH}_{2}-\mathrm{N}_{3}\right)$; IR $\left(\mathrm{KBr}, \mathrm{cm}^{-1}\right): 3108(\mathrm{Ar}-\mathrm{H}), 1669$ $(\mathrm{C}=\mathrm{O}), 1538(\mathrm{Ar}, \mathrm{C}-\mathrm{C}), 1373,1167\left(\mathrm{SO}_{2}\right)$; ESI-MS: $\mathrm{m} / \mathrm{z}$ $463.2\left[\mathrm{M}^{+}\right], 465.2[\mathrm{M}+2]$.
4.1.3.4. 1-(2-Cyano)benzyl-3-benzyl-thieno[3,2-c||1,2,6] thiadiazin-4(3H)-one 2,2-dioxide (5d). Reagents: Compound 4 (1.2 g, $4 \mathrm{mmol})$, 2-cyanobenzyl chloride (0.91 g, $6 \mathrm{mmol})$. Conditions: $80^{\circ} \mathrm{C}, 18 \mathrm{~h}$. Purification: recrystallization. Yield $0.9 \mathrm{~g}(55 \%)$ as a white solid: $\mathrm{mp}$ $102-103{ }^{\circ} \mathrm{C}(\mathrm{EtOH}) ;{ }^{1} \mathrm{H}$ NMR (DMSO- $\left.d_{6}\right) \delta: 8.22(\mathrm{~d}$, $1 \mathrm{H}, J=5.4 \mathrm{~Hz}$, thiophene), 7.89 (d, $1 \mathrm{H}, J=7.8 \mathrm{~Hz}$ benzene $\mathrm{H}-3), 7.65-7.30(\mathrm{~m}, 8 \mathrm{H}$, benzene), $7.22(\mathrm{~d}, 1 \mathrm{H}$, $J=5.3 \mathrm{~Hz}$, thiophene), $5.30\left(\mathrm{~s}, 2 \mathrm{H}, \mathrm{CH}_{2}\right), 5.01(\mathrm{~s}, 2 \mathrm{H}$, $\left.\mathrm{CH}_{2}\right) ;{ }^{13} \mathrm{C}$ NMR (DMSO- $\left.d_{6}\right) \quad \delta: 157.57 \quad(\mathrm{C}=\mathrm{O})$, 143.63(C-1), 138.47(C-1), 136.61, 136.06, 133.79, $129.31,128.71$ (3C), 128.11 (3C), 127.98, 121.27, $119.01(\mathrm{CN}), 117.11(\mathrm{C}-7), 111.05(\mathrm{C}-2), 52.77\left(\mathrm{CH}_{2}-\right.$ $\left.\mathrm{N}_{1}\right)$, $46.06\left(\mathrm{CH}_{2}-\mathrm{N}_{3}\right)$; IR $\left(\mathrm{KBr}, \mathrm{cm}^{-1}\right): 3110(\mathrm{Ar}-\mathrm{H})$, $2231(\mathrm{CN}), 1656(\mathrm{C}=\mathrm{O}), 1535(\mathrm{Ar}, \mathrm{C}-\mathrm{C}), 1382,1176$ $\left(\mathrm{SO}_{2}\right)$; ESI-MS: $\mathrm{m} / z$ 410.5 [M+1].

4.1.3.5. 1-(3-Chloro)benzyl-3-benzyl-thieno[3,2-c][1,2,6]thiadiazin-4(3H)-one 2,2-dioxide (5e). Reagents: Compound 4 (1.2 g, $4 \mathrm{mmol})$, 3-chlorobenzyl chloride (1.0 g, $6 \mathrm{mmol}$ ). Conditions: $80^{\circ} \mathrm{C}, 18 \mathrm{~h}$. Purification: recrystallization. Yield $0.75 \mathrm{~g}(45 \%)$ as a white solid: $\mathrm{mp} 108$ $109{ }^{\circ} \mathrm{C}(\mathrm{EtOH}) ;{ }^{1} \mathrm{H}$ NMR (DMSO- $\left.d_{6}\right) \delta: 8.23(\mathrm{~d}, 1 \mathrm{H}$, $J=5.3 \mathrm{~Hz}$, thiophene), 7.41-7.28 (m, 9H, benzene), 7.10 (d, $1 \mathrm{H}, J=5.3 \mathrm{~Hz}$, thiophene), $5.18\left(\mathrm{~s}, 2 \mathrm{H}, \mathrm{CH}_{2}\right), 4.99$ (s, $\left.2 \mathrm{H}, \mathrm{CH}_{2}\right) ;{ }^{13} \mathrm{C}$ NMR (DMSO- $\left.d_{6}\right) \delta: 157.53(\mathrm{C}=\mathrm{O})$, 143.39(C-1), 137.28(C-1), 136.78, 136.08, 133.42, 130.80, $128.75(2 \mathrm{C}), \quad 128.52, \quad 128.12(2 \mathrm{C}), \quad 128.03(2 \mathrm{C}), \quad 126.65$, $121.05,118.50(\mathrm{C}-7), 53.13\left(\mathrm{CH}_{2}-\mathrm{N}_{1}\right), 45.86\left(\mathrm{CH}_{2}-\mathrm{N}_{3}\right)$; IR $\left(\mathrm{KBr}, \mathrm{cm}^{-1}\right): 3112(\mathrm{Ar}-\mathrm{H}), 1660(\mathrm{C}=\mathrm{O}), 1535(\mathrm{Ar}$, C-C), 1375, $1174\left(\mathrm{SO}_{2}\right)$; ESI-MS: $m / z 419.3[\mathrm{M}+1]$.

4.1.3.6. 1-(3-Cyano)benzyl-3-benzyl-thieno[3,2-c][1,2,6]thiadiazin-4(3H)-one 2,2-dioxide (5f). Reagents: Compound 4 (1.2 g, $4 \mathrm{mmol})$, 3-cyanobenzyl chloride $(0.91 \mathrm{~g}$, $6 \mathrm{mmol})$. Conditions: $80^{\circ} \mathrm{C}, 24 \mathrm{~h}$. Purification: recrystallization. Yield $0.80 \mathrm{~g}(49 \%)$ as a white solid: $\mathrm{mp} 83-85^{\circ} \mathrm{C}$ $(\mathrm{EtOH}) ;{ }^{1} \mathrm{H}$ NMR $\left(\mathrm{DMSO}-d_{6}\right) \delta: 8.25(\mathrm{~d}, 1 \mathrm{H}, J=5.3 \mathrm{~Hz}$, thiophene), $7.80(\mathrm{~d}, 1 \mathrm{H}, J=7.3 \mathrm{~Hz}$ benzene $\mathrm{H}-6), 7.66$ (s, $1 \mathrm{H}$, benzene $\mathrm{H}-2), 7.48-7.28(\mathrm{~m}, 8 \mathrm{H}$, benzene and thiophene), $5.23\left(\mathrm{~s}, 2 \mathrm{H}, \mathrm{CH}_{2}\right) ; 4.99\left(\mathrm{~s}, 2 \mathrm{H}, \mathrm{CH}_{2}\right) ;{ }^{13} \mathrm{C} \mathrm{NMR}$ $\left(\mathrm{DMSO}-d_{6}\right) \delta: 157.43(\mathrm{C}=\mathrm{O}), 143.24(\mathrm{C}-1), 136.89(\mathrm{C}-1)$, $136.45,136.00,132.75,132.33,131.68,130.15,128.72$ (3C), $128.05(3 \mathrm{C}), 121.05(\mathrm{CN}), 118.52(\mathrm{C}-7), 111.70(\mathrm{C}-$ 3), $52.86\left(\mathrm{CH}_{2}-\mathrm{N}_{1}\right), 45.76\left(\mathrm{CH}_{2}-\mathrm{N}_{3}\right)$; IR $\left(\mathrm{KBr}, \mathrm{cm}^{-1}\right)$ : $3107(\mathrm{Ar}-\mathrm{H}), 2231(\mathrm{CN}), 1658(\mathrm{C}=\mathrm{O}), 1534(\mathrm{Ar}, \mathrm{C}-\mathrm{C})$, 1375, $1172\left(\mathrm{SO}_{2}\right)$; ESI-MS: $m / z 410.5$ [M + 1].

4.1.3.7. 1-(2,4-Dichloro)benzyl-3-benzyl-thieno[3,2-c]$[1,2,6 \mid$ thiadiazin-4(3H)-one 2,2-dioxide $(5 \mathrm{~g})$. Reagents: Compound 4 (1.2 g, $4 \mathrm{mmol}$ ), 2,4-dichlorobenzyl chloride $(1.17 \mathrm{~g}, 6 \mathrm{mmol})$. Conditions: $80^{\circ} \mathrm{C}, 24 \mathrm{~h}$. Purification: recrystallization. Yield $0.95 \mathrm{~g}(52 \%)$ as a white solid: mp $112-114^{\circ} \mathrm{C}(\mathrm{EtOH}) ;{ }^{1} \mathrm{H}$ NMR (DMSO- $\left.d_{6}\right) \delta: 8.18$ (d, $1 \mathrm{H}, J=5.3 \mathrm{~Hz}$, thiophene), 7.67-7.28 (m, 8H, benzene), $7.15(\mathrm{~d}, 1 \mathrm{H}, J=5.3 \mathrm{~Hz}$, thiophene), $5.18(\mathrm{~s}, 2 \mathrm{H}$, $\left.\mathrm{CH}_{2}\right) ; 5.03\left(\mathrm{~s}, 2 \mathrm{H}, \mathrm{CH}_{2}\right) ;{ }^{13} \mathrm{C}$ NMR (DMSO-d $\left.d_{6}\right) \delta$ : $157.61(\mathrm{C}=\mathrm{O}), 143.54(\mathrm{C}-1), 136.48(\mathrm{C}-1), 136.07,133.91$, $133.51,131.79,131.28,129.43,128.68(2 \mathrm{C}), 128.12(2 \mathrm{C})$, $127.98,127.88,121.22,118.70(\mathrm{C}-7), 51.51\left(\mathrm{CH}_{2}-\mathrm{N}_{1}\right)$, $45.97\left(\mathrm{CH}_{2}-\mathrm{N}_{3}\right)$; IR $\left(\mathrm{KBr}, \mathrm{cm}^{-1}\right)$ : $3095(\mathrm{Ar}-\mathrm{H}), 1652$ $(\mathrm{C}=\mathrm{O}), 1536(\mathrm{Ar}, \mathrm{C}-\mathrm{C}), 1375,1185\left(\mathrm{SO}_{2}\right)$; ESI-MS: $\mathrm{m} / \mathrm{z}$ $453.3\left[\mathrm{M}^{+}\right]$. 
4.1.3.8. 1-(4-Chloro)benzyl-3-benzyl-thieno[3,2-c][1,2,6]thiadiazin-4(3H)-one 2,2-dioxide (5h). Reagents: Compound 4 (1.2 g, $4 \mathrm{mmol})$, 4-chlorobenzyl chloride (1.0 g, $6 \mathrm{mmol}$ ). Conditions: $80^{\circ} \mathrm{C}, 18 \mathrm{~h}$. Purification: recrystallization. Yield $0.60 \mathrm{~g}(36 \%)$ as a white solid: $\mathrm{mp} 77-79^{\circ} \mathrm{C}$ $(\mathrm{EtOH}) ;{ }^{1} \mathrm{H}$ NMR (DMSO- $\left.d_{6}\right) \delta: 8.22(\mathrm{~d}, 1 \mathrm{H}, J=5.3 \mathrm{~Hz}$, thiophene), 7.42-7.14 (m, 10H, benzene and thiophene), $5.15\left(\mathrm{~s}, 2 \mathrm{H}, \mathrm{CH}_{2}\right) ; 4.98\left(\mathrm{~s}, 2 \mathrm{H}, \mathrm{CH}_{2}\right) ;{ }^{13} \mathrm{C}$ NMR (DEPT) $\left(\mathrm{DMSO}-d_{6}\right) \delta: 157.48(\mathrm{C}=\mathrm{O}), 143.22(\mathrm{C}-1), 136.64(\mathrm{C}-1)$, $136.02,133.57,133.16,130.07(2 \mathrm{C}), 128.78(2 \mathrm{C}), 128.66$ (2C), 128.17(2C), 127.98, 121.24, 118.75(C-7), 53.26 $\left(\mathrm{CH}_{2}-\mathrm{N}_{1}\right)$, $45.71\left(\mathrm{CH}_{2}-\mathrm{N}_{3}\right)$; IR $\left(\mathrm{KBr}, \mathrm{cm}^{-1}\right): 3112(\mathrm{Ar}-$ $\mathrm{H}), 1672(\mathrm{C}=\mathrm{O}), 1535(\mathrm{Ar}, \mathrm{C}-\mathrm{C}), 1376,1173\left(\mathrm{SO}_{2}\right)$; ESIMS: $m / z 419.2[\mathrm{M}+1]$.

4.1.3.9. 1-(4-Bromo)benzyl-3-benzyl-thieno[3,2-c][1,2,6] thiadiazin-4(3H)-one 2,2-dioxide (5i). Reagents: Compound 4 (1.2 g, $4 \mathrm{mmol})$, 4-bromobenzyl chloride $(1.5 \mathrm{~g}, 6 \mathrm{mmol})$. Conditions: $60^{\circ} \mathrm{C}, 8 \mathrm{~h}$. Purification: recrystallization. Yield $0.50 \mathrm{~g}(27 \%)$ as a white solid: mp $91-93{ }^{\circ} \mathrm{C}(\mathrm{EtOH}) ;{ }^{1} \mathrm{H}$ NMR (DMSO- $\left.d_{6}\right) \delta: 8.22(\mathrm{~d}$, $1 \mathrm{H}, J=5.3 \mathrm{~Hz}$, thiophene), 7.45-7.09 (m, 10H, benzene and thiophene), $5.14\left(\mathrm{~s}, 2 \mathrm{H}, \mathrm{CH}_{2}\right), 4.98\left(\mathrm{~s}, 2 \mathrm{H}, \mathrm{CH}_{2}\right)$; ${ }^{13} \mathrm{C}$ NMR (DMSO- $\left.d_{6}\right) \delta$ : $157.48(\mathrm{C}=\mathrm{O}), 143.22(\mathrm{C}-1)$, 136.66(C-1), 136.01, 133.99, 131.71(2C), 130.36(2C), 128.67(2C), 128.17(2C), 127.97, 121.78, 121.21, 118.69 (C-7), $53.29\left(\mathrm{CH}_{2}-\mathrm{N}_{1}\right), 45.71\left(\mathrm{CH}_{2}-\mathrm{N}_{3}\right) ; \mathrm{IR}(\mathrm{KBr}$, $\left.\mathrm{cm}^{-1}\right)$ : 3111( $\left.\mathrm{Ar}-\mathrm{H}\right), 1673(\mathrm{C}=\mathrm{O}), 1536(\mathrm{Ar}, \mathrm{C}-\mathrm{C})$, 1374, $1171\left(\mathrm{SO}_{2}\right)$; ESI-MS: $\mathrm{m} / \mathrm{z} 463.2\left[\mathrm{M}^{+}\right], 465.2$ $[\mathrm{M}+2]$.

4.1.3.10. 1-(4-Cyano)benzyl-3-benzyl-thieno[3,2-c]|1,2,6]thiadiazin-4(3H)-one 2,2-dioxide (5j). Reagents: Compound 4 (1.2 g, $4 \mathrm{mmol})$, 4-cyanobenzyl chloride $(0.91 \mathrm{~g}$, $6 \mathrm{mmol}$ ). Conditions: $80^{\circ} \mathrm{C}, 24 \mathrm{~h}$. Purification: recrystallization. Yield $0.50 \mathrm{~g}(31 \%)$ as a white solid: $\mathrm{mp} 118-119^{\circ} \mathrm{C}$ $(\mathrm{EtOH}) ;{ }^{1} \mathrm{H}$ NMR (DMSO- $\left.d_{6}\right) \delta: 8.24(\mathrm{~d}, 1 \mathrm{H}, J=5.3 \mathrm{~Hz}$, thiophene), 7.74-7.73 (q, 2H, benzene H-4, H-5), 7.41$7.28\left(\mathrm{~m}, 8 \mathrm{H}\right.$, benzene and thiophene), $5.27\left(\mathrm{~s}, 2 \mathrm{H}, \mathrm{CH}_{2}\right)$, $4.99\left(\mathrm{~s}, 2 \mathrm{H}, \mathrm{CH}_{2}\right) ;{ }^{13} \mathrm{C}$ NMR (DMSO-d $\left.d_{6}\right) \delta: 157.45$ $(\mathrm{C}=\mathrm{O}), 143.29(\mathrm{C}-1), 140.38(\mathrm{C}-1), 136.90,136.00,132.74$ (2C), 128.79(2C), 128.69(2C), 128.18(2C), 128.02, 120.92, $118.62(\mathrm{CN}), 118.35(\mathrm{C}-7), 111.20(\mathrm{C}-4), 53.21\left(\mathrm{CH}_{2}-\mathrm{N}_{1}\right)$, $45.76\left(\mathrm{CH}_{2}-\mathrm{N}_{3}\right)$; IR $\left(\mathrm{KBr}, \mathrm{cm}^{-1}\right): 3113(\mathrm{Ar}-\mathrm{H}), 2226$ $(\mathrm{CN}), 1686(\mathrm{C}=\mathrm{O}), 1533(\mathrm{Ar}, \mathrm{C}-\mathrm{C}), 1366,1177\left(\mathrm{SO}_{2}\right)$; ESI-MS: $m / z 410.5[\mathrm{M}+1]$.

4.1.3.11. 1-(4-Nitro)benzyl-3-benzyl-thieno[3,2-c]|1,2,6]thiadiazin-4(3H)-one 2,2-dioxide (5k). Reagents: Compound 4 (1.2 g, $4 \mathrm{mmol})$, 4-nitrobenzyl bromide ( $0.86 \mathrm{~g}$, $6 \mathrm{mmol}$ ). Conditions: $60^{\circ} \mathrm{C}, 8 \mathrm{~h}$. Purification: recrystallization. Yield $0.80 \mathrm{~g}(47 \%)$ as a yellow solid: $\mathrm{mp}$ $147-149{ }^{\circ} \mathrm{C}$ (EtOH); ${ }^{1} \mathrm{H}$ NMR (DMSO- $\left.d_{6}\right) \quad \delta: 8.24$ (d, $1 \mathrm{H}, J=5.3 \mathrm{~Hz}$, thiophene), $8.12-8.10(\mathrm{~m}, 2 \mathrm{H}$, benzene H-3, H-5), 7.43-7.29 (m, 8H, benzene and thiophene), $5.32\left(\mathrm{~s}, 2 \mathrm{H}, \mathrm{CH}_{2}\right), 5.00\left(\mathrm{~s}, 2 \mathrm{H}, \mathrm{CH}_{2}\right) ;{ }^{13} \mathrm{C} \mathrm{NMR}$ (DEPT) (DMSO- $\left.d_{6}\right) \quad \delta: 157.46(\mathrm{C}=\mathrm{O}), 147.39(\mathrm{C}-1)$, 143.28(C-1), 142.37(C-4), 136.95, 136.01, 129.15(2C), 128.66(2C), 128.25(2C), 128.00, 123.93 (2C), 120.95, 118.43(C-7), $52.98\left(\mathrm{CH}_{2}-\mathrm{N}_{1}\right), 45.78\left(\mathrm{CH}_{2}-\mathrm{N}_{3}\right) ;$ IR $\left(\mathrm{KBr}, \mathrm{cm}^{-1}\right): 3098(\mathrm{Ar}-\mathrm{H}), 1684(\mathrm{C}=\mathrm{O}), 1520(\mathrm{Ar}, \mathrm{C}-$ C), $1351\left(\mathrm{NO}_{2}\right), 1380,1177\left(\mathrm{SO}_{2}\right)$; ESI-MS: $\mathrm{m} / \mathrm{z} 430.4$ $[\mathrm{M}+1]$.
4.1.3.12. 1-Cynomethyl-3-benzyl-thieno[3,2-c]|1,2,6]thiadiazin-4(3H)-one 2,2-dioxides (5l). Reagents: Compound 4 (1.2 g, $4 \mathrm{mmol})$, chloroacetonitrile $(0.45 \mathrm{~g}$, $6 \mathrm{mmol}$ ). Conditions: $80^{\circ} \mathrm{C}, 24 \mathrm{~h}$. Purification: recrystallization. Yield $0.80 \mathrm{~g}(60 \%)$ as a white solid: $\mathrm{mp}$ $148-150{ }^{\circ} \mathrm{C}(\mathrm{EtOH}) ;{ }^{1} \mathrm{H}$ NMR (DMSO- $\left.d_{6}\right) \delta: 8.35$ (d, $1 \mathrm{H}, J=5.3 \mathrm{~Hz}$, thiophene), 7.53-7.35 (m, 5H, benzene), $7.33\left(\mathrm{~d}, 1 \mathrm{H}, J=7.14 \mathrm{~Hz}\right.$, thiophene), $5.24\left(\mathrm{~s}, 2 \mathrm{H}, \mathrm{CH}_{2}\right)$; $5.07\left(\mathrm{~s}, 2 \mathrm{H}, \mathrm{CH}_{2}\right) ;{ }^{13} \mathrm{C}$ NMR (DMSO-d $\left.d_{6}\right) \delta: 157.30$ $(\mathrm{C}=\mathrm{O}), \quad 142.11(\mathrm{C}-1), \quad 137.25, \quad 135.75, \quad 128.71(2 \mathrm{C})$, 128.11(2C), 128.09, 122.01, 120.93(C-7), 114.69 (CN), $46.45\left(\mathrm{CH}_{2}-\mathrm{N}_{3}\right), 39.24\left(\mathrm{CH}_{2}-\mathrm{N}_{1}\right)$; IR $\left(\mathrm{KBr}, \mathrm{cm}^{-1}\right)$ : $3091(\mathrm{Ar}-\mathrm{H}), 1686(\mathrm{C}=\mathrm{O}), 1527(\mathrm{Ar}, \mathrm{C}-\mathrm{C}), 1384,1185$ $\left(\mathrm{SO}_{2}\right)$; ESI-MS: $m / z 334.5[\mathrm{M}+1]$.

4.1.3.13. 1-Methyl-3-benzyl-thieno[3,2-c]|1,2,6]thiadiazin-4(3H)-one 2,2-dioxides (5m). Reagents: Compound 4 $(1.2 \mathrm{~g}, 4 \mathrm{mmol}),\left(\mathrm{CH}_{3}\right)_{2} \mathrm{SO}_{4}(0.76 \mathrm{~g}, 6 \mathrm{mmol})$. Conditions: $60{ }^{\circ} \mathrm{C}, 8 \mathrm{~h}$. Purification: recrystallization. Yield $0.30 \mathrm{~g}$ $(24.3 \%)$ as a white solid: $\mathrm{mp}$ 94-96 ${ }^{\circ} \mathrm{C}(\mathrm{EtOH}) ;{ }^{1} \mathrm{H}$ NMR (DMSO- $\left.d_{6}\right) \delta: 8.24(\mathrm{~d}, 1 \mathrm{H}, J=5.3 \mathrm{~Hz}$, thiophene), 7.41-7.36 (m, 5H, benzene), 7.35, $5.04\left(\mathrm{~s}, 2 \mathrm{H}, \mathrm{CH}_{2}\right), 3.41$ $(3 \mathrm{H}) ;{ }^{13} \mathrm{C}$ NMR (DMSO- $\left.d_{6}\right) \delta: 157.66(\mathrm{C}=\mathrm{O}), 145.34(\mathrm{C}-$ $1), 136.56,136.27,128.70,127.94(2 \mathrm{C}), 127.92(2 \mathrm{C})$, 121.06, 120.95, 117.24, $45.75\left(\mathrm{CH}_{2}-\mathrm{N}_{3}\right), 37.06\left(\mathrm{CH}_{3}-\right.$ $\left.\mathrm{N}_{1}\right)$; IR $\left(\mathrm{KBr}, \mathrm{cm}^{-1}\right): 3102(\mathrm{Ar}-\mathrm{H}), 1666(\mathrm{C}=\mathrm{O}), 1540$ (Ar, C-C), 1368, $1175\left(\mathrm{SO}_{2}\right)$; ESI-MS: $m / z 309.5$ [M + 1].

\subsection{Anti-HIV activity assays}

The anti-HIV activity and cytotoxicity were evaluated against HIV-1 strain IIIB and HIV-2 (ROD) in MT-4 cells using the 3-(4,5-dimethylthiazol-2-yl)-2,5-diphenyltetrazolium bromide (MTT) method. ${ }^{17}$ MT-4 cells were suspended in culture medium at $1 \times 10^{5}$ cells $/ \mathrm{mL}$ and infected with HIV at a multiplicity of infection (MOI) of 0.02 . Immediately after viral infection, $100 \mu \mathrm{L}$ of the cell suspension was placed in each well of a flat-bottomed microtiter tray containing various concentrations of the test compounds. Stock solutions of the test compounds were prepared in DMSO at a concentration of $10 \mathrm{mg} / \mathrm{ml}$. After 4 days of incubation at $37^{\circ} \mathrm{C}$, the number of viable cells was determined using the MTT method. Compounds were tested in parallel for cytotoxic effects in uninfected MT-4 cells.

The $50 \%$ effective antiviral concentration $\left(\mathrm{EC}_{50}\right)$ was defined as the compound concentration required to protect $50 \%$ of the virus-infected cells against viral cytopathicity. The $50 \%$ cytotoxic concentration $\left(\mathrm{CC}_{50}\right)$ was defined as the compound concentration required to reduce the viability of mock-infected cells by $50 \%$. The symbol ' $>$ ' is used to indicate the highest concentration at which the compounds were tested and still found to be non-cytotoxic. Average $\mathrm{EC}_{50}$ and $\mathrm{CC}_{50}$ values for at least two separate experiments are presented.

\section{Acknowledgments}

The financial support of this work by National Natural Science Foundation of China (NSFC No. 30772629, No. 30371686), Key Project of The International Cooper- 
ation, Ministry of Science and Technology of China (2003DF000033) and Natural Science Foundation of Shandong Province (Y2003C11) is gratefully acknowledged.

\section{References and notes}

1. AIDS Epidemic Update: December 2006, UNAIDS/ WHO, http://www.unaids.org.

2. Ren, J.; Esnouf, R.; Garman, E.; Somers, D.; Ross, C.; Kirby, I.; Keeling, J.; Darby, G.; Jones, Y.; Stuart, D.; Stammers, D. Nature Struct. Biol. 1995, 2, 293-302.

3. Ding, J.; Das, K.; Tantillo, C.; Zhang, W.; Clark, A. D. J.; Jessen, S.; Lu, X.; Hsiou, Y.; Jacobo-Molina, A.; Andries, K.; Pauwels, R.; Moereels, H.; Koymans, L.; Janssen, P. A. J.; Smith, R. H. J.; Kroeger Koepke, R.; Michejda, C. J.; Hughes, S. H.; Arnold, E. Structure 1995, 3, 365-379.

4. Drake, S. M. J. Antimicrob. Chemother. 2000, 45, 417-420.

5. De Clercq, E. J. Med. Chem. 2005, 48, 1297-1313.

6. De Clercq, E. Expert Opin. Emerging Drugs 2005, 10, 241-273.

7. Arranz, E.; Diaz, J. A.; Ingate, S. T.; Witvrouw, M.; Pannecouque, C.; Balzarini, J.; De Clercq, E.; Vega, S. J. Med. Chem. 1998, 41, 4109-4117.

8. Arranz, M. E.; Díaz, J. A.; Ingate, S. T.; Witvrouw, M.; Pannecouque, C.; Balzarini, J.; De Clercq, E.; Vega, S. Bioorg. Med. Chem. 1999, 7, 2811-2822.

9. Witvrouw, M.; Arranz, M. E.; Pannecouque, C.; Declercq, R.; Jonckheere, H.; Schmit, J. C.; Vandamme, A. M.; Dia,
J. A.; Ingate, S. T.; Desmyter, J.; Esnouf, R.; Van Meervelt, L.; Vega, S.; Balzarini, J.; De Clercq, E. Antimicrob. Agents Chemother. 1998, 42, 618-623.

10. Schafer, W.; Friebe, W. G.; Leinert, H.; Mertens, H.; Poll, T.; von der Saal, W.; Zilch, H.; Nuber, B.; Ziegler, M. L. J. Med. Chem. 1993, 36, 726-732.

11. Martinez, A.; Esteban, A. I.; Castro, A.; Gil, C.; Conde, S.; Andrei, G.; Snoeck, R.; Balzarini, J.; De Clercq, E. Antiviral Chem. Chemother. 2000, 11, 221-230.

12. Martinez, A.; Esteban, A. I.; Castro, A.; Gil, C.; Conde, S.; Andrei, G.; Snoeck, R.; Balzarini, J.; De Clercq, E. Antiviral Chem. Chemother. 2001, 12, 347-351.

13. Martinez, A.; Gil, C.; Castro, A.; Bruno, A. M.; Perez, C.; Prieto, C.; Otero, J. Antiviral Chem. Chemother. 2003, 14, 107-114.

14. Cohen, E.; Klarberg, B. J. Am. Chem. Soc. 1962, 84, 1994 1996.

15. Kloek, J. A.; Leschinsky, K. L. J. Org. Chem. 1976, 41, 4028-4030.

16. (a) Barreca, M. L.; Balzarini, J.; Chimirri, A.; De Clercq, E.; De Luca, L.; Höltje, H. D.; Höltje, M.; Monforte, A. M.; Monforte, P.; Pannecouque, C.; Rao, A.; Zappala, M. J. Med. Chem. 2002, 45, 5410; (b) Barreca, M. L.; Rao, A.; De Luca, L.; Zappala, M.; Monforte, A.-M.; Maga, G.; Pannecouque, C.; Balzarini, J.; De Clercq, E.; Chimirri, A.; Monforte, P. J. Med. Chem. 2005, 48, 3433-3437.

17. Pauwels, R.; Balzarini, J.; Baba, M.; Snoeck, R.; Schols, D.; Herdewijn, P.; Desmyter, J.; De Clercq, E. J. Virol. Methods 1988, 20, 309-321. 